\title{
PENERAPAN MEDIA MONOSA (MONOPOLI BAHASA) BERBASIS KEMANDIRIAN DALAM PEMBELAJARAN DI SEKOLAH DASAR
}

\author{
1,2,3Prodi PGSD Universitas PGRI Semarang \\ 1,2,3J. Sidodadi Timur No. 24 Semarang \\ 'Email: sri.suciati@gmail.com \\ 2Email: ika.septiana@gmail.com \\ 3Email: mei_fita@ymail.com
}

Sri Suciati ${ }^{1}$ Ika Septiana ${ }^{2} \&$ Mei Fita Asri Untari ${ }^{3}$

\begin{tabular}{|c|c|}
\hline ABSTRACT & ABSTRAK \\
\hline $\begin{array}{l}\text { This research applying learning media Monosa } \\
\text { (monopoi bahasa) based on the child's } \\
\text { independence in the classroom. Research and } \\
\text { development (RnD) aims to describe prototype } \\
\text { instructional media monosa independence } \\
\text { based on elementary students. Based on the } \\
\text { analysis of the needs of draft obtained monosa } \\
\text { products, namely media that not only disposable } \\
\text { and made of material that is waterproof, } \\
\text { medium-sized and can be placed on the table. } \\
\text { Learning media containing material that is } \\
\text { diverse and covers all aspects of language skills. } \\
\text { Media with images that vary according to the } \\
\text { material Indonesian elementary school fourth } \\
\text { grade.Based on the validation results showed } \\
\text { that the learning media Monosa fit for use. It can } \\
\text { be used by learners, learning media can also } \\
\text { create an atmosphere of fun and do not } \\
\text { saturate because the learning is done with } \\
\text { playing. After revisions based test experts, media } \\
\text { monosa tested in small classes. Monosa showed } \\
\text { that the media has the effectiveness, the } \\
\text { efficiency, and has appeal to users. Based on } \\
\text { observations made during the study, the media } \\
\text { is capable of providing meaningfulness in } \\
\text { learning, which enhances the value of the } \\
\text { character's ability to work together, } \\
\text { sportsmanship, the activity of individual students, } \\
\text { student independence, critical thinking, and } \\
\text { caring. }\end{array}$ & $\begin{array}{l}\text { Penelitian ini merupakan Penelitian } \\
\text { pengembangan (RnD) yang bertujuan untuk } \\
\text { mendeskripsikan prototype media pembelajaran } \\
\text { Monosa berbasis kemandirian pada siswa SD. } \\
\text { Analisis kebutuhan diperoleh draft produk } \\
\text { Monosa, yaitu media yang tidak hanya sekali } \\
\text { pakai dan terbuat dari bahan yang anti air, } \\
\text { berukuran sedang dan dapat diletakkan di } \\
\text { meja. Media disertai gambar yang beragam } \\
\text { sesuai dengan materi bahasa Indonesia SD kelas } \\
\text { IV. Berdasarkan hasil validasi media } \\
\text { pembelajaran Monosa layak digunakan. Setelah } \\
\text { dilakukan revisi berdasarkan uji ahli, media } \\
\text { Monosa diujicobakan pada kelas kecil. } \\
\text { Didapatkan hasil bahwa media Monosa memiliki } \\
\text { keefektifan, keefisiensian, dan memiliki daya tarik } \\
\text { kepada pengguna. Berdasarkan observasi yang } \\
\text { dilakukan selama pembelajaran, media ini } \\
\text { mampu memberikan kebermaknaan dalam } \\
\text { pembelajaran, yaitu mengembangkan nilai } \\
\text { karakter kemampuan bekerja sama, sportifitas, } \\
\text { keaktifan individu siswa, kemandirian siswa, } \\
\text { berpikir kritis, dan peduli. } \\
\text { Kata kunci: penerapan, media monopoli } \\
\text { bahasa, siswa Sekolah dasar. }\end{array}$ \\
\hline $\begin{array}{l}\text { Keywords: application, media monopo } \\
\text { language, elementary students. }\end{array}$ & \\
\hline
\end{tabular}

How to Cite: Suciati, S., Septiana, I., \& Untari, M. (2015). PENERAPAN MEDIA MONOSA (MONOPOLI BAHASA) BERBASIS KEMANDIRIAN DALAM PEMBELAJARAN DI SEKOLAH DASAR. Mimbar Sekolah Dasar, 2(2), 175-188. doi:http://dx.doi.org/10.17509/mimbar-sd.v2i2.1328.

PENDAHULUAN Pendidikan adalah pilar kehidupan suatu bangsa. Semakin maju pendidikan suatu bangsa maka semakin terarah juga kesejahteraan masyarakatnya. Pengertian pendidikan termuat dalam Undang-Undang Republik 
Sri Suciati, Ika Septiana, dan Mei Fita Asri Untari, Penerapan Media Monosa (Monopoli Bahasa)...

Indonesia Nomor 20 tahun 2003 tentang SISDIKNAS, Pasal 1 menyatakan "pendidikan adalah usaha sadar dan terencana untuk mewujudkan suasana belajar dan proses pembelajaran agar peserta didik secara aktif mengembangkan potensi dirinya untuk memiliki kekuatan spiritual keagamaan, pengendalian diri, kepribadian, kecerdasan, akhlak mulia, serta keterampilan yang diperlukan dirinya, masyarakat, bangsa dan Negara". (Undang-Undang Repulik Indonesia, 2003, p. 2).

Pengembangan kemampuan berbahasa anak di sekolah dilakukan dengan tujuan agar 1) anak dapat mengolah kata secara komprehensif; 2) anak dapat mengekspresikan kata-kata dalam bahasa tubuh yang dapat dipahami oleh orang lain; 3) anak mengerti setiap kata yang didengar dan diucapkan, mengartikan dan menyampaikan secara utuh kepada orang lain, dan 4) anak dapat berargumentasi, meyakinkan orang melalui kata-kata yang diucapkannya (Direktorat Pembinaan TK dan SD, 2007).

guru dapat memanfaatkan kemajuan IPTEK untuk menciptakan proses pembelajaran yang efektif. Selain itu, guru juga harus menguasai strategi pembelajaran agar siswa dapat belajar secara efektif. Strategi pembelajaran dalam hal ini adalah penguasaan guru mengenai model, metode serta media pembelajaran.
Peningkatan keterampilan berbahasa anak dalam pembelajaran bahasa di SD dapat dilakukan dengan strategi bermain. Pembelajaran dengan kegiatan permainan dapat pula dilakukan dengan menggunakan media pembelajaran. Hal tersebut sebagai sarana pembelajaran untuk menciptakan pembelajaran yang aktif, memberikan kesempatan kepada peserta didik untuk belajar mandiri, menyelesaikan permasalahan yang dihadapi dengan cara bermain, dan untuk mencapai tujuan pembelajaran.

Untuk mencapai tujuan pembelajaran dapat difasilitasi oleh media pembelajaran. Media pembelajaran memiliki manfaat dalam membantu proses belajar mengajar baik bagi guru mavapun bagi siswa. Penggunaan media pembelajaran dapat membuat variasi belajar yang baru agar tidak membosankan. Salah satu media pembelajaran yang dapat dikembangkan guru dalam penanaman kemandirian anak, pembelajaran yang menarik, mendidik, dan menyenangkan adalah dengan menggunakan media pembelajaran Monopoli Bahasa yang disingkat menjadi Monosa.

Sikap kemandirian peserta didik perlu ditingkatkan dalam setiap proses pembelajaran, salah satunya pembelajaran bahasa Indonesia. Peserta didik melakukan proses pembelajaran secara mandiri dan menanamkan sikap 
mandiri untuk kehidupan di sekolah dan bermasyarakat.

Media permainan monopoli merupakan salah satu media permainan yang dapat menimbulkan kegiatan belajar yang menarik dan membantu suasana belajar menjadi senang, hidup dan santai. Menurut Fitriyawani (2013, p. 226), hasil penelitian beberapa ahli yang telah menguji kelayakan media permainan monopoli memberikan kesimpulan bahwa media permainan monopoli layak digunakan sebagai media pembelajaran karena media permainan monopoli ini merupakan salah satu media permainan yang dapat menimbulkan kegiatan belajar mengajar yang menarik, hidup, menyenangkan dan santai serta mempunyai kemampuan untuk melibatkan siswa dalam kegiatan belajar mengajar secara aktif dalam memecahkan masalah-masalah yang ada sehingga dapat meningkatkan hasil belajar siswa.

Monosa (monopoli bahasa) merupakan media pembelajaran monopoli dengan memasukkan unsur bahasa dan gambar edukatif yang digunakan dengan cara bermain atau permainan seperti permainan monopoli untuk mengasah keterampilan dan pengetahuan berbahasa peserta didik.

Melalui Permainan dengan menggunakn media dalam pembelajaran dapat mendukung terciptanya rangsangan pada anak dalam berbahasa salah satunya yang diciptakan pendidik sesuai kebutuhan dan kondisi peserta didik maupun kondisi sekolah.

Berdasarkan latar belakang di atas, rumusan masalah penelitiannya (1) Apa sajakah kebutuhan awal pengembangan media Monosa berbasis kemandirian anak pada pembelajaran bahasa Indonesia di Sekolah Dasar (SD)?; (2) Bagaimanakan prototipe pengembangan media Monosa berbasis kemandirian anak pada pembelajaran bahasa Indonesia di Sekolah Dasar (SD)?

\section{METODE}

\section{Desain dan Prosedur Penelitian}

Penelitian ini dilakukan untuk menghasilkan produk media pembelajaran yang dapat meningkatkan pembelajaran bahasa di Sekolah Dasar. Desain penelitian ini dirancang dengan menggunakan penelitian Research dan Development (R\&D). "Desain penelitian Research and Development adalah penelitian dan pengembangan suatu proses atau langkah-langkah untuk mengembangkan suatu produk baru atau menyempurnakan produk yang telah ada, yang dapat dipertanggung jawabkan" (Sukmadinata, 2008, p. 164). Prosedur penelitian dilakukan melalui enam tahap yaitu:

1. Pengumpulan data

Analisis kebutuhan awal menggunakan angket dan 
Sri Suciati, Ika Septiana, dan Mei Fita Asri Untari, Penerapan Media Monosa (Monopoli Bahasa)...

wawancara. Pengumpulan data untuk analisis kebutuhan awal ini dilakukan dengan menyebarkan angket kebutuhan kepada siswa kelas IV SD, guru, dan orang tua siswa SD.

\section{Perencanaan}

Menyusun prototipe media pembelajaran Monosa berdasarkan hasil analisis kebutuhan awal.

\section{Uji Ahli}

Prototipe yang telah dirancang diujikan kepada tiga orang, yaitu ahli media pembelajaran, ahli materi pembelajaran Bahasa Indonesia SD, dan praktisi (guru).

\section{Revisi Uji Ahli}

Penyempurnaan prototipe setelah mendapatkan masukan dari uji ahli.

5. Uji coba terbatas di satu kelas Uji coba di satu kelas.

6. Revisi hasil Uji coba Penyempurnaan prototipe setelah uji coba.

Objek penelitian tahap pertama dilakukan di Kota Semarang. Objek penelitian meliputi Sekolah Dasar Inti dan Sekolah Dasar Imbas yang ada di kota Semarang. Subjek penelitian ini adalah pendidik dan peserta didik Sekolah Dasar di Kota Semarang (tahap pertama). Penelitian dilakukan pada guru Sekolah Dasar yang masuk dalam wadah organisasi Kelompok Kerja Guru (KKG) Sekolah Dasar Kota Semarang yang mewakili setiap Sekolah Dasar di Kota Semarang. Dalam rangka uji prototype akan dilaksanakan di SD Inti dan Imbas di Kota Semarang. Subjek penelitian tahap pertama dalam rangka pengumpulan data analisis kebutuhan awal guru, peserta didik, orangtua, ahli materi dan ahli media.

\section{HASIL DAN PEMBAHASAN}

Hasil penelitian yang akan dilaporkan meliputi tiga hal, yaitu 1) kebutuhan awal pengembangan media Monosa pada pembelajaran bahasa Indonesia di Sekolah Dasar; 2) prototype pengembangan media Monosa berbasis kemandirian anak pada pembelajaran bahasa Indonesia di Sekolah Dasar. Berikut hasil penelitian yang telah dilakukan.

\section{Kebutuhan Awal Pengembangan Media} Monosa pada Pembelajaran Bahasa Indonesia di Sekolah Dasar.

\section{Kebutuhan Awal Guru}

Pengumpulan data kebutuhan awal guru menggunakan teknik non tes yaitu berupa angket. Indikator yang ada dalam angket analisis kebutuhan guru meliputi profil pembelajaran bahasa Indonesia di SD dan profil media monopoli bahasa (Monosa). Profil pembelajaran bahasa Indonesia di SD meliputi 15 pertanyaan. Profil media monopoli bahasa (Monosa) meliputi 4 aspek yaitul) tampilan media; 2) profil monopoli bahasa; 3) profil penggunaan media monosa,dan; 4) penunjang. Penyebaran angket untuk kebutuhan awal dilakukan di SDN Purwoyoso 02 
Semarang, SDN Pedurungan Kidul 04, SDN Sawah Besar 02, SDN Candi 02, dan SD AlHikmah Kendal.

Berdasarkan penelitian awal diperoleh hasil bahwa kebutuhan guru SD dalam pembelajaran bahasa Indonesia menggunakan media monopoli bahasa berbasis kemandirian anak dapat diketahui melalui profil pembelajaran bahasa Indonesia SD. Pernyataan satu, pembelajaran bahasa Indonesia sudah dilakukan sesuai dengan kompetensi dasar berjumlah 23 responden. Pernyataan dua, pembelajaran bahasa Indonesia saat ini sudah menyenangkan bagi peserta didik berjumlah 21 responden. Pernyataan tiga, dalam mengajarkan materi Bahasa Indonesia pada setiap KD mudah berjumlah 13 responden. Pernyataan empat, dalam pembelajaran bahasa Indonesia tidak mengalami kendala dalam penyediaan materi berjumlah 12 responden. Pernyataan lima, dalam pembelajaran bahasa Indonesia tidak mengalami kendala dalam memilih metode yang menyenangkan berjumlah 16 responden. Pernyataan enam, dalam pembelajaran bahasa Indonesia tidak mengalami kendala dalam memilih media yang menyenangkan berjumlah 14 responden.

Hasil penelitian pada indikator profil pembelajaran bahasa Indonesia di SD menunjukkan bahwa masih ada kendala yang dihadapi guru dalam menyiapkan materi pembelajaran, menentukan metode pembelajaran, dan menentukan media pembelajaran yang menyenangkan. Selain itu guru juga kadang - kadang menyelenggarakan pembelajaran Bahasa Indonesia menggunakan metode permainan yang berbasis kemandirian anak.

Kebutuhan guru SD dalam pembelajaran bahasa Indonesia menggunakan media monopoli bahasa berbasis kemandirian anak selain dapat diketahui melalui profil pembelajaran bahasa Indonesia SD, juga dapat diketahui melalui profil media monopoli bahasa (Monosa). Profil media monopoli bahasa terdiri atas tampilan media, profil monopoli bahasa, profil penggunaan media Monosa, dan penunjang.

Berdasarkan hasil penelitian ditunjukkan bahwa tampilan media yang diharapkan guru adalah bentuk media berukuran sedang dan permanen. Hal tersebut diharapkan dapat digunakan dalam pembelajaran yang tidak hanya sekali pakai. Oleh karena itu bahan media yang berbahan permanen diharapkan dapat digunakan juga untuk kurun waktu yang lama dan tidak hanya sekali pakai. Berikut ini hasil penelitian aspek profil monopoli bahasa yang diharapkan guru.

Berdasarkan hasil penelitian ditunjukkan bahwa guru belum pernah melihat monopoli bahasa. Hal itu menunjukkan bahwa monopoli bahasa memang belum ada di masyarakat. Yang 
Sri Suciati, Ika Septiana, dan Mei Fita Asri Untari, Penerapan Media Monosa (Monopoli Bahasa)...

dimaksud "ya" pada pernyataan guru pernah melihat media monopoli bahasa adalah bahwa guru pernah melihat permainan monopoli. Sementara itu, untuk pembelajaran bahasa Indonesia belum pernah melihat. Bahan yang diharapkan adalah bahan yang tahan air atau terbuat dari plastik yang berukuran sedang, bisa ditempel di papan atau tembok, berwarna cerah, ramai, menarik, sederhana, dan bermuatkan materi bahasa Indonesia pada setiap kotak media monopoli bahasa.

Media monopoli bahasa dapat digunakan secara berkelompok, perlu diadakan media monopoli bahasa dalam pembelajaran bahasa Indonesia di SD, bahasa yang digunakan lugas dan sederhana dengan kalimat yang bervariasi. Selain itu, media juga dapat digunakan di dalam ruangan maupun di luar ruangan. Dalam rangka pengembangan dan peningkatan pembelajaran bahasa Indonesia di SD, media yang telah dikembangkan perlu ditinjau kembali agar tidak ketinggalan zaman. Hal tersebut dilakukan juga untuk menyesuaikan dengan kurikulum yang digunakan dan perkembangan teknologi.

\section{Kebutuhan Awal Siswa}

Analisis kebutuhan awal juga diperoleh dari angket yang diisi oleh siswa. Siswa menyatakan bahwa materi pembelajaran Bahasa Indonesia mudah dipahami jika dilakukan dengan metode pembelajaran yang menyenangkan.
Salah satu metode yang digunakan adalah bermain. Media permainan monopoli yang ditawarkan adalah media yang menarik dan dapat dilakukan berkelompok.

Tampilan media monopoli bahasa yang diinginkan berdasarkan penelitian awal adalah berukuran sedang, dapat digunakan secara berkelompok, dimainkan dengan diletakkan di meja atau lantai. Gambar dalam monopoli bahasa beragam yang menunjukkan keanekaragaman budaya bangsa Indonesia, berwarna menarik.

Unsur penunjang dalam monopoli bahasa yang diinginkan adalah menggunakan kalimat yang lugas dan sederhana dalam kartu kesempatan dan dana umum. Peninjauan materi dilakukan setiap enam bulan sekali.

\section{Kebutuhan Awal Orang Tua} Kebutuhan awal penelitian dalam rangka pengembangan media pembelajaran Monosa selain dilakukan pada guru dan peserta didik juga dilakukan pada orang tua. Hal tersebut dilakukan untuk mendeskripsikan bagaimana perkembangan peserta didik ketika berada di rumah dan untuk mendeskripsikan pengetahuan orang tua mengenai media pembelajaran. Orang tuayang dimaksud dalam kebutuhan awal ini adalah orang tua pesertadidik SD kelas IV sesuai dengan objek penelitian. 
Orang tua setuju jika ada permainan monopoli yang di dalamnya memuat materi pelajaran. Maka kehadiran monopoli bahasa dibutuhkan siswa untuk mendalami pelajaran di rumah. Profil media dan tampilan media Monosa yang diinginkan orang tua hampir sama dengan yang diinginkan siswa dan guru. Media Monosa berukuran sedang, dapat digunakan secara berkelompok, berwarna cerah, dan memuat gambar tentang wawasan nusantara.

\section{Prototype Media Monosa}

Media Pembelajaran Monosa merupakan media pembelajaran yang menggunakan alat atau media monopoli yang dikembangkan sesuai kebutuhan pembelajaran bahasa. Proses penggunaan media pembelajaran Monosa tidak jauh berbeda dengan permainan monopoli. Yang membedakan antara media Monosa dengan permainan monopoli adalah dalam penggunaan media Monosa tidak menggunakan properti seperti rumah dan hotel yang ada dalam permainan monopoli pada umumnya. Dalam penggunaan media Monosa menggunakan kartu soal yang ada dibagian danau dan kesempatan, sedangkan alas atau papan yang digunakan dimedia Monosa dikembangkan dengan menggunakan gambar yang disesuaikan dengan kebutuhan pembelajaran bahasa Indonesia di SD. Dalam pelaksanaannya guru dapat menerapkan pembelajaran tematik dengan mengaitkan pembelajaran lain atau materi lain yang ada. Dengan penggunaan media Monosa dapat membantu guru dan peserta didik untuk mengingat maupun mengaitkan dengan materi yang lain sehingga peserta didik akan mengingat kembali materi apa yangtelah dipelajari.

Media pembelajaran Monosa yang telah dikembangkan untuk memudahkan penggunaaan media disertai cara penggunaan media Monosa. Berikut ini cara pengunaan media Monosa.

a. Masing-masing tim/kelompok menerima 1 media pembelajaran Monosa.

b. Peserta didik menentukan pemain 4 orang dan 1 sebagai petugas Bank.

c. Peserta didik bersama-sama membaca buku pedoman penggunaan Monosa.

d. Peserta didik melaksanakan petunjuk yang ada di buku pedoman.

e. Petugas bank memimpin doa sebelum permainan dimulai.

f. Petugas bank membagi modal ke pemain.

g. Peserta memilih alat untuk bermainnya itu hewan-hewanan.

h. Petugas bank menata kartu dana umum dan kesempatan di papan atau lembar Monosa sesuai tempatnya.

i. Petugas bank menata sisa uang sebagai simpanan bank. 
Sri Suciati, Ika Septiana, dan Mei Fita Asri Untari, Penerapan Media Monosa (Monopoli Bahasa)...

j. Petugas bank menyimpan label menghitung sisa vang yang dimiliki nama.

k. Peserta menentukan urutan pemain dan menentukan nilai sesuai dengan dengan cara melempar dadu. Peserta yang dadunya menunjukkan jumlah terbanyak maka mendapat urutan pertama dan seterusnya.

I. Peserta meletakkan alat permainan di kolom START.

m. Peserta siap bermain dengan menggunakan alat permainan masing-masing dengan cara melempar dadu dan menjalankan sesuai jumlah dadu yang dilempar.

n. Petugas bank mengawasi dan mengontrol permainan agar berlangsung lancar dan tertib.

o. Semua peserta didik mentaati tata tertib permainan.

pedoman nilai yang sudah ada.

q. Peserta menyerahkan uang sisa vang dan menyampaikan nilai ke petugas bank.

r. Petugas bank mencatat pada lembar nilai kemudian menyerahkan ke guru.

s. Peserta didik bersama-sama merapikan media dan menyerahkan kempali perangkat media keguru.

t. Peserta didik bersama guru melakukan evaluasi dan refleksi.

Perlengkapan yang ada dalam media pembelajaran Monosa meliputi papan atau alas monopoli, dadu, uang, kartu dana umum, kartu kesempatan, label nama gambar, dan alat untuk bermain.

p. Apabila permainan sudah selesai maka masing-masing peserta

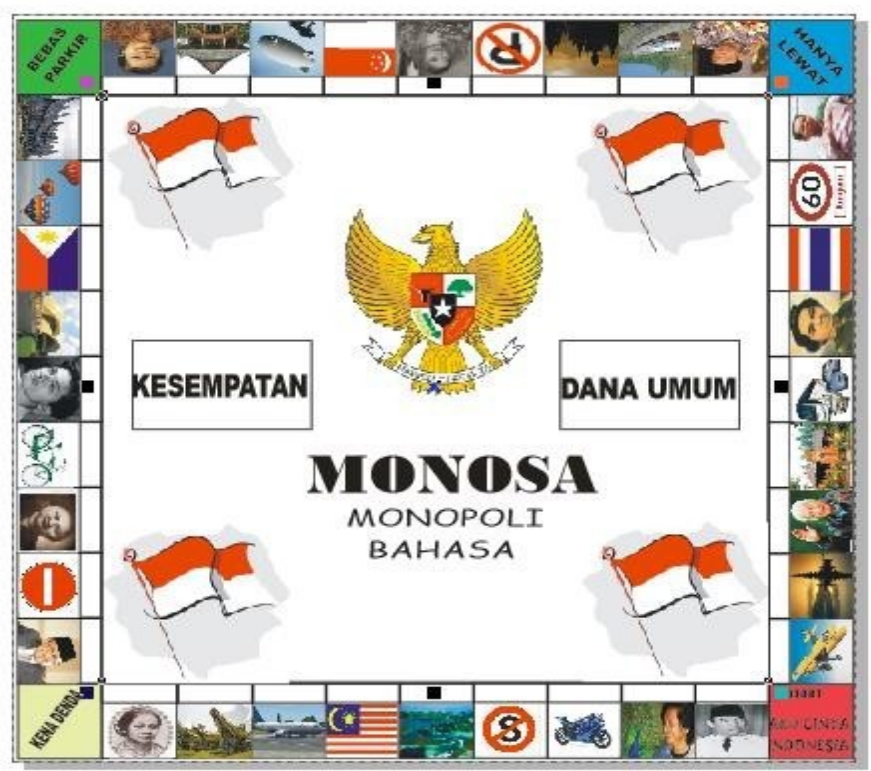

Gambar 1.Prototipe Media Monosa. 

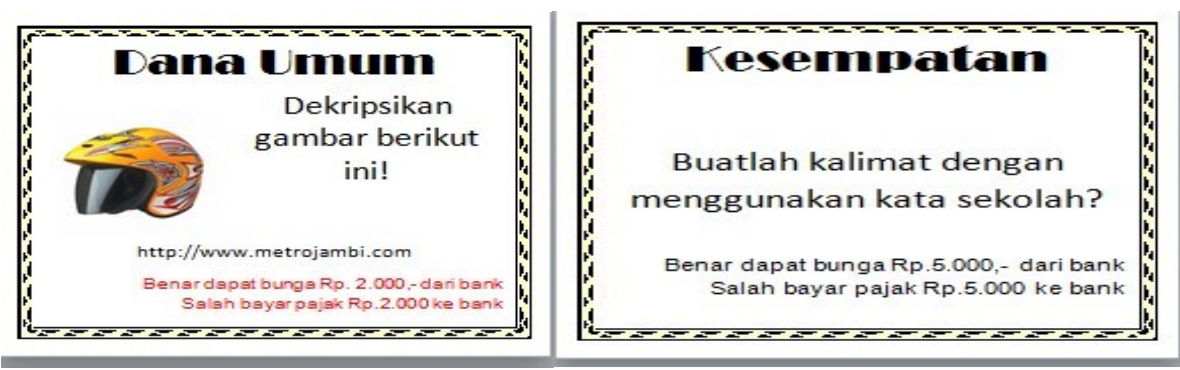

Gambar 2. Kartu Dana Umum dan Kartu Kesempatan

\begin{abstract}
Validasi Ahli
Validasi media Monosa dilakukan oleh ahli media pembelajaran, ahli materi pembelajaran Bahasa Indonesia, dan praktisi yaitu guru SD.
\end{abstract}

Validator menyatakan bahwa media Monosa layak digunakan dalam pembelajaran Bahasa Indonesia di SD dengan beberapa revisi untuk penyempurnaan.

Beberapa hal disarankan oleh ahli materiadalah (1) kurangnya penggunaan istilah asing dan diganti dengan Bahasa Indonesia; (2) halaman yang ada di buku prototipe media diganti dan disesuaikan dengan bahasa Indonesia; (3) peserta di sub bab A dan B pada buku prototipe kata peserta diganti pemain. Peserta berbeda dengan peserta didik; (4) jumlah vang diberikan sebagai modal perlu disebutkan; (5) pada kesempatan masih terlihat menunjuk ke salah satu agama, sebaiknya bersifat umum, karena peserta didik berasal dari agama yang berbeda; (6) belum ada kompetensi menulis.
Penilaian dari ahli media pembelajaran, adalah (1) pertanyaan yang ada di papan atau lembar Monosa menarik perhatian siswa; (2) gambar yang dipilih dalam papan Monosa sudah beragam dan terbaca oleh siswa; (3) Dadu yang digunakan dalam bermain sebaiknya terbuat dari bahan yang lebih awet, misalnya dari kayu; (4) Alat yang digunakan bermain, yaitu macammacam hewan sudah menarik siswa, tetapi pilih hewan yang ukurannya lebih besar; (5) bahan media Monosa sebaiknya yang tahan air dan awet, misalnya dari bahan MMT.

Penilaian dari praktisi, adalah pernyataan gambar yang ada di media pembelajaran Monosa dapat disesuaikan dengan pembelajaran bahasa Indonesia SD kelas IV, soal yang ada di kartu dana umum mencerminkan kebutuhan soal siswa di SD kelas IV, kalimat soal atau petunjuk yang ada di kartu dana umum dan kesempatan sudah sesuai dengan keterbacaan siswa kelas IV SD.

Hasil validasi menyatakan bahwa media Monosa sangat baik diterapkan 
Sri Suciati, Ika Septiana, dan Mei Fita Asri Untari, Penerapan Media Monosa (Monopoli Bahasa)...

pada pembelajaran topik apa pun, tema apa pun, di kelas IV. Hal tersebut menjadikan siswa lebih aktif dan atraktif, kreatif, inovatif dalam proses kegiatan pembelajaran di kelas. Berdasarkan penilaian dan masukan dari validator maka ada revisi dalam pembuatan media Monopoli berbahasa sesuai dengan saran yang diberikan.

\section{Uji Coba Terbatas}

Uji coba terbatas dilakukan di SD N Pedurungan Kidul 02 Semarang dengan sampel 1 kelas yaitu kelas IV.Uji coba dilakukan untuk mengetahui nilai keefektifan produk, nilai keefisiensian produk, dan nilai ketertarikan pengguna pada produk. Setelah produk divalidasi oleh ahli media, ahli materi, dan praktisi, media direvisi sesuai saran. Kemudian produk media Monosa diujikan dengan materi kalimat dan wacana dalam Bahasa Indonesia. Siswa diberi materi oleh guru dan selanjutnya siswa dibagi dalam enam kelompok.

Masing-masing kelompok diberi seperangkat permainan monopoli bahasa. Guru menjelaskan aturan permainan seperti yang tertulis pada buku panduan penggunaan media Monosa. Setelah siswa paham guru memberikan kebebasan kepada siswa untuk membagi siapa yang bermain dan siapa yang bertugas sebagai petugas bank. Hal ini dilakukan untuk mengembangkan kemandirian siswa dalam mengelola permainan setiap kelompok.

Guru berkeliling mengamati proses bermain sambil memberikan solusi jika ada permasalahan. Guru memberikan waktu 30 menit kepada siswa untuk bermain, kemudian dicatat perolehan vang masing-masing siswa dalam kelompok. Hal ini dilakukan untuk mengukur karekter sportifitas dan kejujuran. Kemudian di akhir pembelajaran guru memberikan evaluasi untuk mengukur pemahaman siswa terhadap materi.

Berdasarkan lembar pengamatan yang dilakukan peneliti didapatkan hasil bahwa produk media Monosa memiliki nilai keefektifan, yaitu siswa menjadi lebih aktif, mampu menjawab pertanyaan guru dengan benar, dan mampu menceritakan pengalaman sesuai permainan yang dialami.

Media Monosa juga memiliki nilai efisiensi karena waktu pembelajaran lebih efisien, bermakna. Guru dan siswa merasa terbantu dengan adanya media Monosa dan siswa lebih mudah menyerap materi yang disampaikan. Siswa juga mampu memainkan Monosa secara mandiri di luar jam pembelajaran. 


\section{PEMBAHASAN}

Menurut Sadiman (1986, p7-8) "Media dalam arti terbatas sebagai peraga atau alat bantu pembelajaran, yang sering disebut AVA (Audio Visual Aids). Dalam pemanfaatannya, AVA tidak terlepas dari guru, sedangkan media dapat berdiri sendiri tanpa kehadiran guru". Perbedaan antara media dengan alat peraga sebenarnya terletak pada fungsinya, bukan pada bentuknya. Pendapat lain datang dari Gerlach dan Ely (dalam Kustandi dan Sutjipo, 2013, p. 7) "secara garis besar, media adalah manusia, materi atau kejadian yang membangun kondisi agar siswa mampu memperoleh pengetahuan, keterampilan atau sikap". Guru, buku teks, dan lingkungan sekolah merupakan media. Secara lebih khusus, pengertian media dalam proses belajar mengajar cenderung diartikan sebagai alat-alat grafis, fotografis, atau elektronik untuk menangkap, memproses, dan menyusun kembali informasi visual atau verbal. Sama halnya dengan Kustandi dan Sutjipto, (2013, p. 8) "media pembelajaran adalah alat yang dapat membantu proses belajar mengajar dan berfungsi untuk memperjelas makna pesan yang disampaikan, sehingga dapat mencapai tujuan belajar". Berdasarkan uraian jelaslah bahwa media pembelajaran merupakan segala alat yang dimanfaatkan untuk membantu dalam proses belajar mengajar, yang mempunyai fungsi untuk memperjelas pesan atau materi yang disampaikan agar dapat mencapai tujuan pembelajaran yang optimal dan lebih baik.

Adanya media pembelajaran memiliki berbagai fungsi yang tujuannya untuk membantu dalam proses pembelajaran. Menurut Kemp dan Dayton (dalam Kustandi, 2013, p. 20) media pembelajaran dapat memenuhi tiga fungsi utama apabila media itu digunakan untuk perorangan, kelompok atau kelompok yang besar jumlahnya, yaitu: (1) untuk memenuhi fungsi motivasi, media pembelajaran dapat direalisasikan dengan teknik drama atau hiburan. Hasil yang diharapkan adalah melahirkan minat dan merangsang para siswa atau pendengar untuk bertindak (turut memikul tanggung jawab, melayani secara sukarela, atau memberikan sumbangan material). Pencapaian tujuan ini akan mempengaruhi sikap, nilai, dan emosi; (2) untuk tujuan informasi, media pembelajaran dapat digunakan dalam rangka penyajian informasi dihadapan sekelompok siswa. Isi dan bentuk penyajian bersifat amat umum, berfungsi sebagai pengantar, ringkasan laporan, atau pengetahuan latar belakang. Penyajian dapat pula berbentuk hiburan, drama, atau teknik motivasi. Ketika mendengar atau menonton bahan informasi, para siswa bersifat pasif.Partisipasi yang diharapkan dari siswa hanya terbatas pada persetujuan atau ketidaksetujuan mereka secara mental, atau terbatas pada perasaan 
Sri Suciati, Ika Septiana, dan Mei Fita Asri Untari, Penerapan Media Monosa (Monopoli Bahasa)...

tidak/kurang senang, netral, atau senang; (3) media berfungsi untuk tujuan instruksi di mana informasi yang terdapat dalam media itu harus melibatkan siswa baik dalam benak atau mental maupun dalam bentuk aktivitas yang nyata sehingga pembelajaran dapat terjadi.

Materi harus dirancang secara lebih sistematis dan psikologis dilihat dari segi prinsip-prinsip belajar agar dapat menyiapkan instruksi yang efektif. Di samping menyenangkan, media pembelajaran harus dapat memberikan pengalaman yang menyenangkan dan memenuhi kebutuhan perorang siswa.

Berbicara mengenai media Monosa yang menjadi fokus penelitian merupakan hasil modifikasi dari permainan monopoli. Menurut Wikipedia Indonesia (2015), monopoli adalah salah satu permainan papan yang paling terkenal di dunia. Tujuan permainan ini adalah untuk menguasai semua petak di atas papan melalui pembelian, penyewaan dan pertukaran properti dalam sistem ekonomi yang disederhanakan.

Media monopoli merupakan media pembelajaran yang dapat digunakan dengan cara bermain sehingga memberi siswa situasi-situasi yang menyenangkan, tidak membosankan dan mudah untuk mengekspresikan ide-ide dan perasaan yang tidak akan dapat diterima orang lain, untuk mempermudah siswa dalam menjawab pertanyaan.

Media permainan monopoli merupakan salah satu media permainan yang dapat menimbulkan kegiatan belajar yang menarik dan membantu suasana belajar menjadi senang, hidup dan santai. Permainan monopoli diharapkan mempunyai kemampuan untuk melibatkan siswa dalam kegiatan belajar mengajar secara aktif untuk memecahkan masalah yang ada dan berkompetensi menjadi pemenang dalam permainan.

Media monopoli ini juga memotivasi siswa agar memperoleh pengetahuan sebanyak-banyaknya, karena siswa yang menjawab banyak soal benar maka akan mendapatkan vang mainan sehingga nantinya kelompoknya akan memenangkan permainan tersebut.

Permainan monopoli digunakan sebagai media pembelajaran karena secara umum siswa sudah mengenal permainan tersebut, sehingga kegiatan belajar mengajar yang dilakukan akan lebih menarik dan suasana akan menjadi santai namun juga memperoleh banyak pengetahuan. Media monopoli termasuk dalam media pembelajaran dua dimensi atau grafis.

Pembelajaran dengan menggunakan media Monosa mengedepankan proses dengan hal yang menyenangkan. Penggunaan media 
Monosa akan menghasilkan pembelajaran yang maksimal dan tujuan pembelajaran akan tercapai. Siswa merasa tidak jenuh atau bosan karena pembelajaran dilakukan dengan permainan. Materi soal yang disediakan pada dana umum dan kartu kesempatan dapat mengukur kompetensi siswa sesuai dengan materi pembelajaran.

Urgensi atau pentingnya penggunaan media Monopoli Bahasa pada pembelajaran Bahasa Indonesia di SD adalah sebagai alat bantu guru dalam melaksanakan pembelajaran bahasa Indonesia dan meningkatkan kreativitas guru dalam melakukan pembelajaran. Guru lebih inovatif dalam menyiapkan media pembelajaran dan alat evaluasi pembelajaran. Selain itu dengan penggunaan media Monosa ini siswa lebih kreatif dan menarik dalam mengikuti pembelajaran. Pembelajaran dengan media Monosa ini mengajarkan kepada siswa untuk belajar lebih mandiri dan kreatif. Pembelajaran dilakukan dengan bermain. Siswa melakukan pembelajaran sambil bermain dengan menggunakan media monopoli bahasa. Dalam media monopoli bahasa dilengkapi dengan soal atau tes yang nantinya secara langsung harus dijawab peserta didik. Media monopoli bahasa ini mengkolaborasikan antara pembelajaran Bahasa Indonesia dengan permainan monopoli.

\section{SIMPULAN}

Berdasarkan hasil penelitian yang telah dilakukan diperoleh data bahwa kebutuhan awal penelitian yang dilakukan pada peserta didik, guru, dan orang tua mengharapkan adanya pengembangan media pembelajaran. Responden sangat setuju apabila ada media pembelajaran permainan yang memadukan antara proses pembelajaran dan permainan dalam pembelajaran. Media pembelajaran yang diharapkan adalah media pembelajaran yang menarik dan inovatif. Selama ini responden belum pernah melihat adanya media pembelajaran Monopoli bahasa tetapi untuk permainan monopoli responden sudah mengetahui itu.

Berdasarkan hasil kebutuhan awal tersebut maka dibuat media pembelajaran sesuai dengan kebutuhan awal kemudian dilakukan validasi oleh ahli materi, media, dan praktisi. Berdasarkan hasil validator diperoleh hasil bahwa media pembelajaran Monosa sangat bagus dan sangat menarik. Media pembelajaran tersebut diharapkan dapat diterapkan dalam pembelajaran di SD dan mengaitkan dengan pembelajaran lain. Media pembelajaran yang dikembangkan sudah sesuai dengan pembelajaran SD yang menggunakan pendekatan tematik. Dengan penggunaan media pembelajaran tersebut diharapkan peserta didik tidak merasa jenuh atau bosan karena pembelajaran dilakukan 
Sri Suciati, Ika Septiana, dan Mei Fita Asri Untari, Penerapan Media Monosa (Monopoli Bahasa)...

dengan bermain. Meskipun dengan bermain kompetensi dan tujuan pembelajaran tetap tercapai karena dengan adanyasoal pada lembar dana umum dan kesempatan. Berdasarkan hasil uji coba terbatas media Monosa memiliki nilai keefektifan, keefisiensian, dan ketertarikan pengguna terhadap produk.

\section{REFERENSI}

Direktorat Pembinaan TK dan SD. (2007). Pedoman pembelajaran Bidang Pengembangan Bahasa di Taman Kanak-kanak. Jakarta: Kemendiknas.

Fitriyawani, (2013). Penggunaan Media Permainan Monopoli Melalui Pembelajaran Kooperatif pada Mahasiswa Fisika Fakultas Tarbiyah dengan Konsep Tata Surya, Jurnal IImiah DIDAKTIKA, 13 (2), 223-239.

Hardjito, dkk. (2011). Kemampuan guru SD dalam perencanaan intim (inovasi, teknik, dan model) pembelajaran sastra.Penelitian APBI IKIP PGRI Semarang.

Kustandi, C. (2013). Media pembelajaran. Bogor: Ghalia Indonesia.

Oktavianti, R., \& Wiyanto, A. (2014). PENGEMBANGAN MEDIA GAYANGHETUM (GAMBAR WAYANG HEWAN DAN TUMBUHAN) DALAM PEMBELAJARAN TEMATIK TERINTEGRASI KELAS IV SD. Mimbar Sekolah Dasar, 1(1). $\quad$ 65-70. doi:http://dx.doi.org/10.17509/mimbarsd.v1i1.865.

Sadiman, A. (1986). Media pendidikan, pengertian, pengembangan, dan. pemanfaatannya. Jakarta: Rajawali.

Sudjana, Nana. (2005). Media pengajaran. Bandung: Sinar Baru Algensin.
Wikipedia Indonesia. (2015). Monopoli. [Online] diakses dari (https://en.wikipedia.org/wiki/Monopol i. 